\title{
KEMAMPUAN MEMBACA ANAK SEKOLAH DASAR KELAS RENDAH BAGIAN DARI PENGEMBANGAN BAHASA
}

\author{
Sunanih \\ Universitas Muhammadiyah Tasikmalaya \\ Jl.Tamansari Km. 2,5 Tamansari Kota Tasikmalaya \\ Email: sunanihsyima@yahoo.co.id
}

\begin{abstract}
Technological era that is increasingly growing and sophisticated demands the support of growing culture as well, as well as reading culture is not less important with other cultures. Reading culture should be a necessity and a habit. To respond to these demands, it raised internal polemic that children want to enter elementary school must have been able to read, meanwhile early childhood should not be taught to read. This writing aims to open the parents/educations'perception to understand how to teach reading for early childhood and young learner appropriate with their characteristics and their developments where this problem not become a polemic again in society. In the field, there are many interesting reading methods for children, so it becomes educators' duty, both parents and teachers to choose or create an appropriate method for early childhood and young learner (elementary school beginner), of course which not become a burden for them. Thus, basically teaching reading for young learner is allowed with appropriate method and children development where they are introduced with interesting letters, so it increases their curiosity. Therefore, inculcating reading ability is important, because reading ability is part of language improvement for early childhood and young learners ( elementary school beginner).
\end{abstract}

Keywords:

Elementary school students, methods, reading

\begin{abstract}
Abstrak
Zaman teknologi yang semakin berkembang dan semakin canggih menuntut dukungan budaya semakin berkembang pula, begitu juga dengan budaya membaca tidak kalah penting dengan budaya-budaya lainya. Budaya baca harus menjadi kebutuhan, kegemaran dan kebiasaan. Untuk menyikapi tuntutan-tuntutan tersebut melahirkan polemik internal antara tuntutan dimana anak mau masuk sekolah dasar (SD)harus sudah mampu membaca dan pendaapat anak usia dini belum boleh diajarkan membaca. Penulisan artikel ini bertujuan membuka wawasan bagi para orang tua/pendidik untuk memahami bagaimana mengajar anak membaca sesuai dengan karakteristi dan perkembangannya dimana hal ini tidak menjadi polemik lagi di masyarakat. Dilapangan sudah banyak metodemetode membaca yang menarik bagi anak, dengan demikian ini tugas para pendidik baik orang tua maupun guru untuk memilih atau menciptakan metode yang tepat bagi anak usia dini/ anak SD kelas rendah, tentunya yang tidak membebani. Jadi Pada dasarnya mengajarkan membaca bagi anak usia dini itu boleh-boleh saja asalkan dengan metode yang sesuai dengan perkembangannya dimana anak diperkenalkan dengan berbagai hurup yang menarik sehingga menimbulkan rasa penasaran dan keingin tahuan. Dengan demikiann menanamkan kemampuan membaca itu penting, karena membaca bagian dari perkembangan bahasa bagi anak usia dini/ anak SD kelas rendah.
\end{abstract}

Kata kunci:

Anak SD kelas Rendah; Metode; Membaca.

\section{A. PENDAhULUAN}

Dikalangan masyarakat banyak para ibu yang sangat hawatir anaknya tidak bisa membaca, obrolan kecil dengan orang tua yang mempunyai anak usia dini mereka ratarata hawatir takut anak nya tidak bisa membaca ketika masuk sekolah dasar, sebab masuk SD rata-rata sekolah unggulan mempunyai kriteria anak sudah bisa membaca. Dengan adanya kehawatiran tersebut ahirnya tidak sedikit orang tua yang memasukan les anaknya sejak dini, bukan hanya membaca bahkan banyak orang tua yang memberikan berbagai les kepada 
anaknya, yang terkadang bukan memberikan kesenangan pada anak yang memang seharusnya di berikan sesuai dengan masa perkembangannya, tapi malah memberikan tekanan bagi anak dan banyak anak-anak yang bermasalah akibat pola asuh yang diberikan oleh orang tuanya sendiri.

Dengan adanya hal tersebut sangatlah penting mengkaji tentang bagaimana sebenarnya bembaca bagi anak SD kelas rendah, agar ada sedikit pencerahan bagi para orang orang tua dan guru yang membutuhkan pengetahuan tentang ini. Sehingga dapat memberikan sedikit solusi bagi putra putri tercinta.

Dalam hal ini tentunya Masalah membaca bagi anak SD kelas rendah sangat menarik untuk di bahas kaitannya dengan masalah perkembangan anak yang sangat sensitif dan harus hati-hati. Dimana anak usia 0-8 tahun masa perkembangannya pesat sekali mulai dari aspek psikomotorik, kognitif, sosial, emosional, bahasa maupun agama

(https://www.parentingclub.co.id/smartstories/mengenal-tahap-perkembanganpsikologi-anak-dari-tahun-ke-tahun)

\section{B. HASIL DAN PEMBAHASAN}

\section{Kemampuan membaca Anak Usia Sekolah Dasar Kelas Rendah}

Anak usia SD kelas rendah yaitu anak usia kelas 1sampai kelas II atau Kelas III, dimana anak pada usia ini pikirannya masih melekat bagaimana menyenangkannya pada masa bermain di PAUD sebagaimana diungkapkan oleh Para ahli pendidikan anak usia dini adalah anak usia 0- 8 tahun, sebagaimana di ungkapkan oleh Prof. Marjorry Ebbeck (1991) seorang pakar anak usia dini dari australia menyatakan bahwa pendidikan anak usia dini adalah pelayanan pada anak mulai dari lahir sampai usia delapan tahun tahun. Jadi anak usia SD kelas rendah masih digolongkan kepada kategori anak usia dini, sehingga perlakuanpun harus spesial termasuk dalam mengajarkan membaca.

Teori lama mengatakan bahwa yang disebut anak adalah anak usia dewasa mini masih polos dan belum bisa apa-apaatau dengan kata lain belum mampu berfikir ( hartati, 2007: 10) pemahaman ini berdampak pada pola perlakuan yang diberikan pada anak antara lain anak sering diperlakukan sebagai layaknya orang dewasa atau diperlakukan sebagai orang dewasa kecil, mungkin masih segar dalam ingatan masa kecil kita ketika dipakaikan baju kebaya pake konde, berpakaian layaknya orang dewasa dan sebagainya. Seiring dengan berkembangnya ilmu pengetahuan banyak dilakukan studi tentang anak maka semakin diketahui bahwa anak sangat berbeda dengan orang dewasa.

Adapun pendapat yang berbeda dari teori lama mereka menganggap anak merupakan manusia yang memiliki potensi yang harus dikembangkan ( Hartati, 2007:) ia memiliki karakteristik tertentu yang khas yang berbeda tentunya dengan orang dewasa serta akan berkembang menjadi manusia dewasa seutuhnya.

Manusia sejak lahir telah dibekali potensi yang harus dikembangkan sebagainama diungkapkan di dalam AlQur'an ( QS:Annhl :78 ) yang artinya:" Dan Alloh telah mengeluarkan kamu dari perut ibumu dengan tidak mengetahui suatu apapun dan Dia memberimu pendengaran, penglihatan dan hati nurani agar kamu bersyukur".

Pengertian ayat Allah SWT telah memberi bekal potensi/kemampuan pada setiap manusi berupa pendengaran, penglihatan jikalau potensi ini dikembangkan dengan baik maka hasilnya akan baik membentuk hati nurani yang baik. Agar semua itu terwujud maka anak harus dibekali pengalaman yang baik dalam interaksi 
dengan lingkungan terutama lingkungan keluarga.

Menurut Rahman (2002:31) bahwa "pengalaman yang dialami anak pada usia dini akan berpengaruh kuat terhadap kehidupan selanjutnya" pengalaman tersebut akan bertahan lama bahkan tidak dapat terhapuskan. Bila suatu saat ada stimulasi yang memancing pengalaman hidup yang pernah dialaminya maka efek tersebut akan muncul kembali dalam bentuk yang berbeda. Kepentingan pendidik memberi pengalaman yang berkesan yang akan berdampak pada kehidupan anak pase berikutnya.

Kemampuan membaca bagi SD kelas rendah merupakan kemampuan yang kompleks yang dapat dikuasai melalui proses bertahap selama masa perkembangan anak, karena ada proses yang bertahap, tidak salah jika anak dipersiapkan sejak dini untuk mengenal dan menguasai kemampuan awal membaca. Kemampuan awal bahasa anak adalah bahasa ibunya, dengan demikian anak yang diasuh oleh ibunya yang cerewet, banyak bicara maka anaknya cenderung lebih cepat perkembangan bahasanya dan sebaliknya anak yang diasuh oleh ibunya yang pendiam bahkan tuna wicara anak akan kesulitan bicara hingga ia dewasa, dengan demikian hampir semua pakar pendidikan sepakat bahwa cerita merupakan media pembelajaran bahasa yang sangat kaya (suyadi. 2014:207).

Dengan demikian mengembangkan bahasa bagi anak adalah bagaimana kecerdasan seorang ibu mendekati anak selalu menyenangkan dengan pendekatan bahasa atau bercerita yang menarik bagi anak, secara tidak langsung anak akan bisa dengan sendirinya bahkan kemampuan membaca pun akan mengikutinya tanpa harus bersusah payah. Akan tetapi Dilapangan seringkali orang tua tidak menyadari menuntut anak cepat bisa baca, apalagi melihat anak lain yang seusia anaknya sudah bisa baca, padahal kemampuan anak berbeda-beda, jangan sampai anak setres karena tuntutan orang tua. Kita tau dunia anak adalah dunia bermain sehingga segala upaya yang dilakukan orang tua untuk merangsang pertumbuhan dan perkembangan anak harus dengan cara yang menyenangkan bagi anak termasuk mengenalkan baca. karena tidak mudah bagi anak untuk konsentrasi duduk manis fokus membaca, dengan karakternya yang relatif aktif pada masa usia ini. Anak melakukan proses belajar melalui pengalaman hidupnya. Pengalaman yang baik dan menyenangkan akan berdampak positif bagi perkembangannya, demikian juga sebaliknya, anak belajar dari segala yang ia lihat, ia dengar dan ia rasakan. Sebagaimana diungkapkan didalam Proses belajar anak akan berjalan efektif apabila anak ada dalam kondisi senang dan bahagia. Sebaliknya proses belajar diterima anak dalam suasana takut, cemas, was-was dan perasaan lain yang tidak nyaman, tidak akan mampu memberikan hasil yang optimal.

Mengajarkan membaca menjadi suatu kewajiban bagi orang tua dan guru, pepatah mengatakan bahwa "Membaca adalah jendela dunia dan ilmu pengetahuan". Katakata bijak tersebut mengandung makna yang dalam bahwa membaca merupakan alat utama untuk memahami dunia dan ilmu pengetahuan yang ada di dalamnya. Dalam ayat AlQur'an Qs: 96 ayat 1 dan 3) "Bacalah dengan menyebut nama tuhanmu yang menciptakan, bacalah dan tuhanmu yang maha mulia". Membaca merupakan bagian penting dalam kehidupan manusia, karena sebagai pintu gerbang pengetahuan, seseorang dengan kemampuan membacanya dan menulis bisa mendapatkan informasi yang dibutuhkan untuk meningkatkan pengetahuannya.

Kegiatan membaca bukan hanya perlu dilakukan di lingkungan sekolah, melainkan juga untuk banyak tugas fungsional di lingkungan luar sekolah. Oleh karena itu, belajar membaca hendaknya sudah mulai 
ditanamkan sejak usia dini dengan harapan mereka kelak memiliki kegemaran membaca. Menanamkan gemar membaca pada anak tidaklah mudah seperti sulitnya mengenalkan huruf ini semua perlu waktu ketekunan dan keuletan namun para pendidik anak usia dini/SD kelas rendah tidak usah panik, mengajarkan membaca pada anak pilih metode yang praktis untuk menumbuhkan minat baca bagi anak yang sudah bisa dan mahir menbaca (Ajeng Yusriana,(2012: 45) begitu juga mengenalkan huruf bagi pemula dalam membaca harus memilih metode yang menarik dan tidak membosankan.

Hainstock (2002:85) menyebutkan bahwa membaca merupakan pengenalan huruf-huruf atau bunyi huruf dengan cara melihat, menyentuh dan mendengarkan setiap huruf yang diucapkan satu persatu kemudian digabungkan untuk membentuk kata-kata pendek. Adapun menurut Shofi (2008:21) berpendapat bahwa membaca bagi anak usia dini merupakan aktivitas kompleks yang mencakup fisik (gerakan mata dan ketajaman penglihatan), aktivitas mental (daya ingat) dan pemahaman. Lebih lanjut Shofi mengemukakan bahwa setiap anak akan dapat membaca dengan baik bila mampu melihat huruf-huruf dengan jelas dapat menggerakkan mata secara lincah, memahami simbol-simbol bahasa secara tepat, dan memiliki penalaran yang cukup untuk memahami bacaan.

Selanjutnya Menurut Prasetyono (2008:170) bahwa belajar membaca dan menulis bagi anak bersifat auto telic artinya, belajar mempunyai daya tarik bagi anak-anak kecil karena mereka ingin belajar untuk kesenangan. Belajar bukan dorongan oleh rasa takut, persaingan, atau pujian. Jadi diusahakan menghilangkan setiap tekanan yang bisa dirasakan oleh anak. Sebagaimana diketahui bahwa anak usia dini berada pada tahap praoperasional, pada tahap ini anak sudah bisa menggunakan kata-kata utuh dalam menggambarkan suatu objek. Tahap ini merupakan tahap perkembangan yang sangat penting dalam perkembangan bahasa anak, karena pengalaman berbahasa dumilai pada tahap ini. Dengan demikian tahap ini mempunyai pengaruh yang kuat terhadap perkembangan selanjutnya.

Membaca adalah suatu proses yang dilakukan dan dipergunakan oleh pembaca untuk memperoleh pesan yang disampaikan penulis melalui media kata-kata/bahasa tertulis (Tarigan, 1983: 7). Proses kegiatan membaca itu dimulai dari penguasaan kosa kata atau pembendaharaan kata, kemudian pemahaman kalimat, paragraf, dan sampai pada pembahasan wacana (suryatin, 1990: 23). Untuk dapat membaca dengan baik maka perlu disertai dengan kesiapan membaca.

\section{Metode Membaca Bagi Anak Usia SD kelas rendah}

Banyak sekali pilihan metode membaca bagi anak sekolah SD kelas rendah diantaranya yaitu:

a. Metode Alfabet

Metode ini sering disebut metode harfiah "ABC method" awalnya dikenalkan huruf abjad dari A-Z, setelah hafal lalu huruf-huruf dirangkai menjadi suku kata, lalu suku kata di rangkai menjadi kata dan terciptalah kalimat.

b. Metode Suara

Metode suara disebut " phonic method" metode ini penyempurnaan dari alfabet pada metode ini yang diajarkan adalah bunyibunyi bahasa sebagai pengganti Huruf-huruf tersebut. Ucapan huruf-huruf tidak berdasarkan bunyi atas bunyi abjadnya melainkan ucapan hurufnya.

c. Metode suku kata

Dalam metode ini suku kata merupakan kunci pokok dalam membuat kata, metode suku kata sebenarnya suatu metode mengajarkan membaca permulaan yang didasarkan atas kata-kata dianalisis menjadi suku kata , suku kata -suku kata tersebut di 
intensiskan menjadi kata-kata. Metode katakata

d. Metode cerita

Metode ini selalu diawali dengan katakata tertulis, setelah kata-kata itu dikenalkan lalu kata-kata itu dianalisis atas suku katanya, lalu dianalisis lagi atas hurufhurufnyabarulah disambungkan lagi dalam bentuk kata semula. EX: da-da gi-gi ku-ku.

e. Metode kata-kata

Metode ini diawali menghafalkan cerita atau sebuah puisi, lalu diuraikan atas kalimatkalimatnya. Sampai pada kata-katanya.

f. Metode SAS ( struktural analitik sintetik)

Adapun contoh pelaksanaan metode SAS sebagai berikut: Mula-mula diberikan kalimat secara keseluruhan. Kalimat itu diuraikan atas kata-kata yang mendukungnya. Dari kata-kata itu kita ceraikan atas suku-suku katanya dan akhirnya atas huruf-hurufnya. Kemidian huruf-huruf itu kita sintetiskan kembali menjadi suku kata, suku kata menjadi kata dan kata menjadi kalimat. (http://www.gurusd.net/2015/11)

\section{Menurut}

http://pustakapaud.blogspot.co.id/2016/08), dalam takdiroatun Musfiroh (2009: 59) ada dua metode membaca permulaan yaitu linier dan whole language pada dasarnya metode tersebut di keluarkan oleh dua tokoh tersebut adalah sama, yaitu:

a) Menurut Membaca dari bawah (bottom up) atau juga disebut linear yaitu membaca dari yang sederhana ke yang lebih rumit. Hal ini juga ditegaskan oleh Slamet Suyanto (2005: 166) bahwa salah satu metode pembelajaran membaca yang dikenal adalah metode fonik yaitu mengeja huruf demi huruf saat membaca atau menulis kata, lebih lanjut dikemukakan pula bahwa suara dalam kata diwakili oleh huruf yang dapat disusun menjadi kata. Jadi dapat disimpulkan bahwa pada metode bottom up anak diajarkan membaca dengan mengenalkan huruf dan bunyi huruf, suku kata, kata dan kalimat secara berurutan.

b) Membaca dari atas ke bawah (top down) atau Whole language yaitu anak belajar melalui pemahaman bentuk utuh. Anak belajar secara umum mengenali kata secara utuh dan baru memaknainya. Lebih lanjut diungkapkan bahwa pada metode whole language anak tidak boleh dikenalkan abjad namun kata secara utuh.

Mengenal kata merupakan bagian dari membaca permulaan, sebelum membaca permulaan anak dikenalkan kata terlebih dulu. Mengenal kata sejak dini dapat bermanfaat bagi anak untuk persiapan membaca dijenjang yang lebih lanjut. Oleh karena itu perlu dilakukan stimulasi yang tepat, sehingga dapat mengembangkan kemampuan anak dalam mengenal kata sebagai modal agar dapat membaca. Dengan modal awal pengenalan kata pada anak usia dini, para orang tua mestinya tidak cemas lagi anak masuk SD tidak bisa membaca. Melancarkan membaca adalah tugas guru dan orang tua ketika anak sudah terangsang dengan keinginan bisa membaca, para pendidik tidak akan kesusahan untuk mengarahkannya. Belajar membaca dengan paksaaan itu tidak boleh, sebab akan menimbulkan kejenuhan pada tahap perkembangan berikutnya.

\section{Membaca Merupakan keterampilan Berbahasa}

Bahasa merupakan alat yang digunakan oleh anak untuk hidup bersama orang lain, bisa dibayangkan jika hidup tidak bisa berbicara tentunya akan kesulitan berinteraksi dalam kehidupan sosial. Kemampuan berbicara merupakan anugerah Allah SWT yang harus dipelihara dengan baik sebagaimana firmannya: “ dia 
menciptakan manusia. Mengajarnya pandai berbicara" ( QS. Ar-Rahman: 3-4).

Membaca dan menulis adalah merupakan salah satu dari empat keterampilan berbahasa atau (language arts, language skills). Keempat keterampilan tersebut yaitu: a) keterampilan menyimak / mendengarkan ( listening skills ). b) keterampilan berbicara ( speaking skills ). c) keterampilan membaca ( reading skills) d) keterampilan menulis ( writing skills). ( Tarigan, 1983: 1).

Begitu pula dengan pendapat baron Brown S. Rebeca (1990: 5) bahwa: "A teacher must integrate the four language groups of listening, speaking, and writing as well as all content areas that extent learning". Dengan demikian membaca bagian dari kemampuan berbahasa dan ada empat pokok konteks pengembangan bahasa yaitu mendengarkan, berbicara, membaca dan menulis.

Diungkapkan pula oleh Novan Ardy Wiyani ( 2014: 103) pengembangan kemampuan bahasa meliputi pengembangan aspek mendengar, berbicara, menulis, dan membaca. Berdasarkan aspek kemampuan anak usia dini, aspek kemampuan bahasa yang paling utama dikembangkan adalah kemampuan mendengar dan berbicara. Keempat keterampilan berbahasa sebagaimana disebutkan oleh para ahli diatas, pada dasarnya merupakan satu kesatuan yang tidak bisa dipisahkan, begitu pula setiap keterampilan berbahasa erat kaitannya dengan proses berfikir seseorang.

Mulanya bahasa dan pikiran anak berbeda, kemudian perlahan, sesuai tahap perkembangan mentalnya, bahasa dan pikiran menyatu hingga bahasa merupakan ungkapan dari pikiran. Anak secara alami belajar bahasa dari interaksinya dengan orang lain untuk berkomunikasi yaitu menyatakan pikiran dan keinginannya dan memahami pikiran dan keinginan orang lain. Bukanlah manusia itu makhluk sosial yang selalu bergaul, bermasyarakat dan bergaul dengan orang lain oleh karena itu belajar bahasa yang paling efektif ialah bergaul dan berkomunikasai dengan orang lain. Vigotsky (Slamet Suyanto, 2005: 171-172).

Sebagaimana diungkapkan oleh Novan Ardy Wiyani ( 2014: 97)perkembangan bahasa pada anak usia dini merupakan perubahan sistem lambang bunyi yang berpengaruh terhadap kemampuan berbicara anak usia dini.dengan kemampuan berbicaranya itu anak usia dini bisa mengidentifikasi dirinya serta berinteraksi dan bekerja sama dengan orang lain.

Membaca merupakan suatu keterampilan yang kompleks, rumit, mencakup atau melibatkan serangkaian keterampilanketerampilan yang lebih kecil. Dengan perkataan lain, keterampilan membaca mencakup tiga komponen, yaitu: 1) pengenalan terhadap aksara serta tanda-tanda baca. 2) korelasi aksara beserta tanda-tanda baca dengan unsur-unsur linguistik yang formal. 3) hubungan lebih lanjut dari satu dan dua dengan makna atau meaning

Broughton dalam tarigan, 1983: 10). Lebih lanjut, tarigan menegaskan bahwa secara garis besarnya terdapat dua aspek penting dalam membaca, yaitu: Pertama keterampilan yang bersifat mekanis ( mechanical skills ) yang dapat dianggap berada pada urutan yang lebih rendah ( lower order ). Aspek ini mencakup: 1) ketermpilan yang bersifat mekanis ( mechanical skills yang dapat di pengenalan bentuk huruf. 2) pengenalan unsur-unsur linguistik (fonem/grafen, kata, frase, pola klause, kalimat dan lain-lain). 3) Pengenalan hubungan korespondensi pola ejaan dan bunyi (kemampuan menyuarakan bahan tertulis). 4) Kecepatan membaca bertaraf lamban. Kedua keterampilan yang bersifat pemahaman ( komprehension skills ) yang dianggap berada pada urutan tang lebih tinggi ( higher order ). Aspek ini mencakup: a) memahami pengertian sederhana (leksikal, 
gramatikal, retorikal). b) Memahami signifikansi atau makna (relevansi/keadaan kebudayaan reaksi pembaca). c) Evaluasi atau penilaian (isi, bentuk). d) Kecepatan membaca yang fleksibel yang mudah disesuaikan dengan keadaan.

Untuk mencapai tujuan yang terkandung dalam keterampilan mekanis tersebut menurut tarigan aktifitas yang paling sesuai adalah membaca nyaring. Dan untuk keterampilan pemahaman maka aktifitas yang paling tepat adalah membaca dalam hati.

Menurut penelitian yang telah dilakukan di Eropa, anak yang telah matang untuk masuk sekolah dasar, telah menguasai peletakan relasi dalam bahasa yang digunakannya menurut taraf perkembangan di lingkungannya ( Depdikbud, 1977: 4). Piaget ( Tarigan, 1985: 7). Lebih lanjut menjelaskan penguasaan bahasa pada anak sebagai berikut: Usia 0,0 - 0,5 tahun, tahap meraba (pralinguistik) pertama. Usia 0,5 1,0 tahun, tahap meraban (pralinguistik) kedua. Usia 1,0 - 2,0 tahun, Tahap linguistik 1: Holoprastik ; Kalimat satu kata. Usia 2,03,0 tahun, tahap linguistik 11: Kalimat/ ucapan satu kata. Usia 3,0- 4,0 tahun, Tahap linguistik III: Pengembangan tata bahasa. Usia 4,0-5,0 tahun, tahap linguistik IV: Tata bahasa menjelang dewasa. Usia 5,0 tahun, tahap linguistik V: Kompetensi penuh.

Anak usia prasekolah berada pada rentang usia 4-6 tahun mengalami perkembangan yang pesat dalam banyak hal baik dalam perkembangan motorik, bahasa maupun kognitif. Dalam hal ini Solalhuddin (2006: 46) mengemukakan:

"Pada usia ini anak memiliki kehidupan fantasi yang kaya dan menuntut lebih banyak kemandirian. Dengan kehidupan fantasi yang dimilikinyaini, anak memperlihatkan kesiapan untuk mendengarkan cerita-cerita secara lebih lama, anak menyenangi dan menghargai sajak-sajak sederhana. Beberapa anak bahkan dapat mengingatnya. Begitupun kemandirian yang dituntutnya membuat ia tidak mau banyak diatur.Pada usia 4 5 tahun, rasa ingin tahu dan sikap antusias yang siap terhadap segala sesuatu merupakan ciri yang menonjol. Anak memiliki sikap berpetualang yang kuat. Kualitas lain dari si anak usia ini adalah abilitas untuk memahami pembicaraan san pandangan orang lain semakin sehingga keterampilan komunikasinyapun meningkat".

Mencermati kutipan di atas dapat disimpulkan bahwa anak memiliki kesiapan untuk belajar bahasa melalui mendengar cerita dan sajak-sajak sederhana, rasa ingin tahunya tinggi dan kemampun untuk berkomuniksi semakin meningkat.

Pengembangan bahasa anak usia dini/SD kelas rendah merupakan salah satu dominan perkembangan anak yang dalam pelaksanaannya tidak dapat dipisahkan dari semua kegiatan anak. Menurut Eliason (1994:163), "Every part of rich early childhood curriculum should offer the opportunity for literacy development". Semua kegiatan, baik itu yang berkaitan dengan musik, IPS, matematika, sains, dan kegiatan apapun pengalaman lainnya harus memberi kesempatan untuk mengembangkan keterampilan berbahasa.

Pengembangan bahasa anak dirumah ataupun di taman kanak-kanak/paud/SD kelas rendah harus mengintegrasikan empat unsur keterampilan berbahasa sebagaimana diucapkan oleh para ahli diatas, jadi Pengembangan bahasa yang dilakukan orang tua dan guru harus mendukung terhadap upaya pengembangan yang secara tidak sadar juga dilakukan oleh anak, pendidik sebagai model dalam segala hal baik ucapan maupun kegiatan akan di tiru setiap hari oleh anak. keterampilan berbahasa sangat penting bagi perkembangan anak usia dini mereka harus diarahkan agar memiliki kemampuan bahasa yang baik sejak dini, potensi yang ada pada 
diri anak merupakan tanggung jawab pendidik, pendengarannya, penglihatannya, perasaannya harus benar-benar terjaga agar anak berkembang sesuai harapan.

\section{SIMPULAN}

Setiap orang tua mendambakan anakanaknya tumbuh dan berkembang sehat jasmani dan rohani, sehat secara fisik dan fsikis, sehat akal dan jiwanya, pendidikan SD kelas rendah masih tergolong anak usia dini tentunya berbeda dengan pendidikan lainnya, pada masa ini pendidikan memerlukan pendekatan yang unik, sabar dan kreatif, disesuaikan dengan masa perkembangannya yang unik pula. Begitu pula dengan pendekatan mengenalkan membaca orang tua/guru dituntut harus memahami perkembangan anak sehingga mengajarkan membaca bisa berhasil secara optimal tanpa merusak perkembangan anak atau menjadikan tekanan bagi anak.

Stimulus yang diberikan kepada anak usia/ SD kelas randah akan berdampak hingga anak usia dewasa, setiap orang tua tentunya menginginkan anak-anaknya tumbuh dan berkembang dengan baik sehingga dambaan memiliki regenerasi cerdas saleh salehah bisa terwujud. Untuk memenuhi tuntutan kemampuan membaca bagi anak yang tidak boleh dilupakan oleh para pendidik yang paling utama metode yang menarik dan pendekatan kepada anak dengan tulus dan penuh kasih sayang, berusaha bagaimana anak bisa nyaman dengan pendidik sehingga metode apapun yang yang disampaikan kepada anak, mereka akan senang menerimanya.

\section{DAFTAR PUSTAKA}

Ardy Wiyani Novian, ( 2014).Psikologi perkembangan Anak Usia Dini, Yogyakarta: GAVA MADIA

Rahman Hibana S (2005). Konsep Dasar Pendidikan anak Usia Dini. Yogyakarta. Grafindo Litera Media.
Hartati, T(1998). The Effectiveness of steinberg Early Reading, Program on the Ability of Reading at Preschool Level, Malaysia: University Sains.

Sunaryo, Selamet, (2005). Dasar-Dasar Pendidikan Anak Usia Dini, Hikayat Publishing.

Suryatin, H.E. (1990). Keterkaitan Antara Minat Baca Sastra Indonesia dan Pengalaman Belajar Sastra indonesia dengan Tingkat Kemampuan Apresiasi Sastra Indonesia. Tesis Program S-2 . Bandung: IKIP.

Sconell, F.J,. Essential in Teaching and Testing Spelling, London: MC Mollan and Co. , Ltd

Sofie, Madjid, Abdul, Belajar Mudah Membaca Al-Qur'an,(Bimbingan Belajar dari "Nol" Sampai Tamat AlQur'an, Metode BBQ-99. Bandung: Elfath. (2007).

Yusriana Ajeng. Kiat-kiat Menjadi guru PAUD yang Disukai Anak-Anak, jogjakarta: DIVA Press. (2012).

Depdikbud, Program Akta Mengajar V-B Komponen Bidang Studi Bahasa Indonesia, Buku II, Modul: masalah membaca: Proyek Pengembangan Institut Perguruan Tinggi. (1983).

Eliason, C. Dan Jenkins, L. Practical Guide to Early Childhood Curriculum. New York: Merril Print of Mac Millan College. (1994).

http://pustakapaud.blogspot.co.id/2016/08/pe ngertian-metode-membaca-permulaanpada-anak-usia-dini.html

http://www.gurusd.net/2015/11/aspekmembaca-permulaan-di-kelasrendah.html

https://www.parentingclub.co.id/smartstories/mengenal-tahapperkembangan- psikologi-anak-daritahun-ke-tahun

Solehuddin. Konsep DasarPendidikan Prasekolah, Bandung: Fakultas Ilmu 
Pendidikan Universitas Pendidikan Indonesia. (2000).

Suyanto,S. Konsep dasar Pendidikan Anak Usia Dini, Jakarta:Departemen pendidikan Nasional. (2005).

Semiawan, C.R.(2002). Belajar dan Pembelajaran Prasekolah dan Sekolah Dasar, Jakarta: P.T. Indek

Tarigan, H.G. Membaca Sebagai Suatu keterampilan Berbahasa, Bandung: Angkasa.. (1983). 